\title{
Maintaining Road Infrastructure Sustainability through Weighbridge Policy
}

\author{
Kismartini $^{1}$, Yuliana Kristanto ${ }^{2}$ \\ $\left\{\right.$ kis_martini@yahoo.co.id ${ }^{1}$ \} \\ Universitas Diponegoro, Indonesia ${ }^{1,2}$
}

\begin{abstract}
Transportation sustainability has become one of today's global environmental issues. In addition, this issue has been studied from various perspectives. This study aims to evaluate how the Indonesian government maintains the sustainability of road transportation through the policy of weighing heavy vehicles on the road (PerdirhubdatRegulation of Directorate of Transportation on Road Map of Implementation Revitalization for Weighing Motorized Vehicle). The study used descriptive qualitative method by obtaining information from stakeholders, i.e. BPTD (Balai Pengelola Transportasi Darat/Land Transportation Management Office) of Region X of Central Java and Special Region of Yogyakarta (DIY) provinces, the Head Coordinator of UPPKB (Unit Pelaksana Penimbangan Kendaraan Bermotor/Implementation Unit of Motorized Vehicle Weighing) of Batang, Brebes and Rembang regencies; Team Commander (Komandan Regu-Danru) at UPPKB, Drivers of Goods Transportation, public communities as Road Users and observing directly at 3 weighbridge points. The results showed that the implementation of revitalization program for weighing motor vehicles was not yet fully maximal. This can be seen from the evaluation indicators including effectiveness which shows less maximal results since because it was not based on the predetermined operational standards. Whereas efficiency showed that it was still ineffective both in terms of cost and energy.
\end{abstract}

Keywords: Sustainable Transportation, Policy Evaluation, Weighbridge, Efficiency.

\section{Introduction}

Transportation sector has been the biggest contributor to current global environmental problems. This is due to the fact that transportation activities have contributed to the emission of exhaust gases that damage the ozone layer of which it will ultimately result in global warming. Besides, the use of fuel for motor vehicles can emit pollutants such as $\mathrm{CO}$, NOx, SOx, dust, hydrocarbons as well as lead $\left(\mathrm{P}_{\mathrm{b}}\right)$. Air contaminated by these substances can cause health problems whose different levels and types.

Data from the Ministry of Energy and Mineral Resources (ESDM) of the Republic of Indonesia noted that energy consumption in Indonesia reached 1, 23 billion Barrels Oil Equivalent (BOE) in 2017, 9\% higher than the previous year. Based on its designation, it turned out that transportation is the second biggest users after household needs. The largest national energy as much as 382,94 million BOE or $31 \%$ of the total energy is used for household purposes. In addition, the second largest user, 361.7 million BOE or around $29.31 \%$, is transportation sector and the third, 273,86 million BOE or $22.19 \%$ of the total 
national energy consumption, is for industry (Ministry of Energy and Mineral Resources/ESDM, 2018).

Transportation problems in Indonesia are indeed extremely complex, besides the problem of air pollution from vehicles' exhaust gas; there are also physical road problems in road transportation [1]. Road damage often not to mention as almost always occurs in National Road Route 1, which is the main road of Java Island, well known as Pantura lane (Northern Coast highway line). According to the Ministry of Public Works and Public Housing (PUPRPekerjaan Umum dan Perumahan Rakyat), the damage in Pantura lane was mainly caused by the passing trucks which are mostly overloaded.

Road damage, essentially in highway, will definitely affect the safety of road users as well as the energy used for transportation modes will increase and eventually cause disruption, dust and air pollution, to the surrounding area. These things indicate that the land transportation system, especially in Pantura lane (northern coast highway line), does not yet meet the criteria for Sustainable Transportation.

Sustainable Transportation is defined as a collection of transportation activities as well as infrastructure which does not cause problems or costs for future generations to solve and bear the burden [2]. Hence, it can be concluded that it is expected that by sustainable transportation there will be the use of transportation modes and other transportation infrastructure that cooperate to accelerate transportation activities and drive the regional economy development without leaving and/or causing problems in the future. Damage to national roads can be seen from the percentage of highway stability, which is shown in the figure 1.

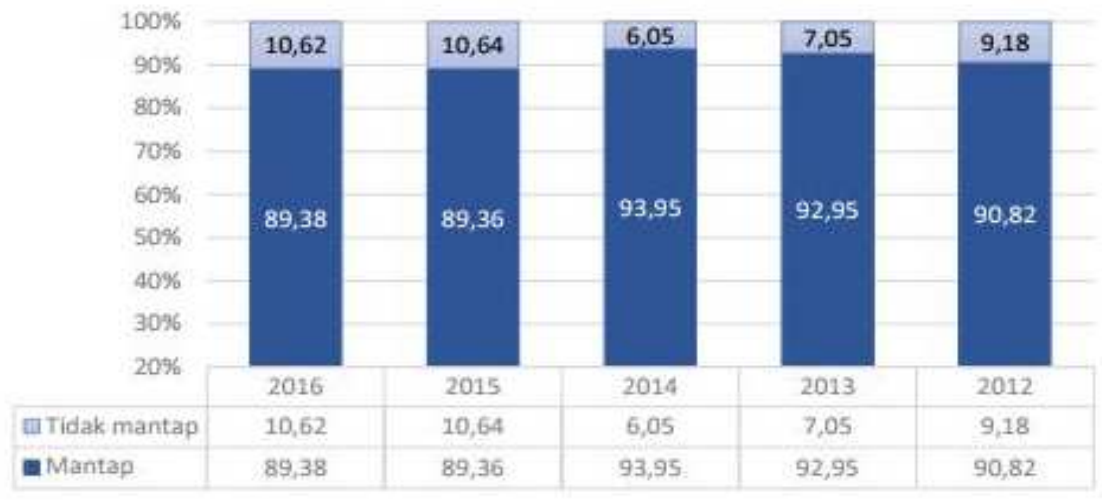

Fig.1. Percentage of National Road Stability Year 2012-2016.

Source: Pusdata (Central Data)-Ministry of Public Works.

The data described in Figure 1 shows an increase in the percentage of damaged road facilities from 2015 to 2016 . Accordingly, it can be concluded that an increase in the number of overloaded vehicles could be one factor causing the increase in damaged roads.

The most recently case occurred on April 18, 2018 where Cincin Lama Bridge connecting Babat sub-district of Lamongan regency and Widang sub-districts of Tuban regency, East Java Province, was unable to withstand the tonnage loads from cargo transportation which exceeded its cargo capacity. Based on police investigation, the incident of Cincin Lama Bridge collapse was caused by over-tonnage of three trucks which reached 120 tons. In contrast, the bridge was only able to withstand 45 tons of total vehicle load. 


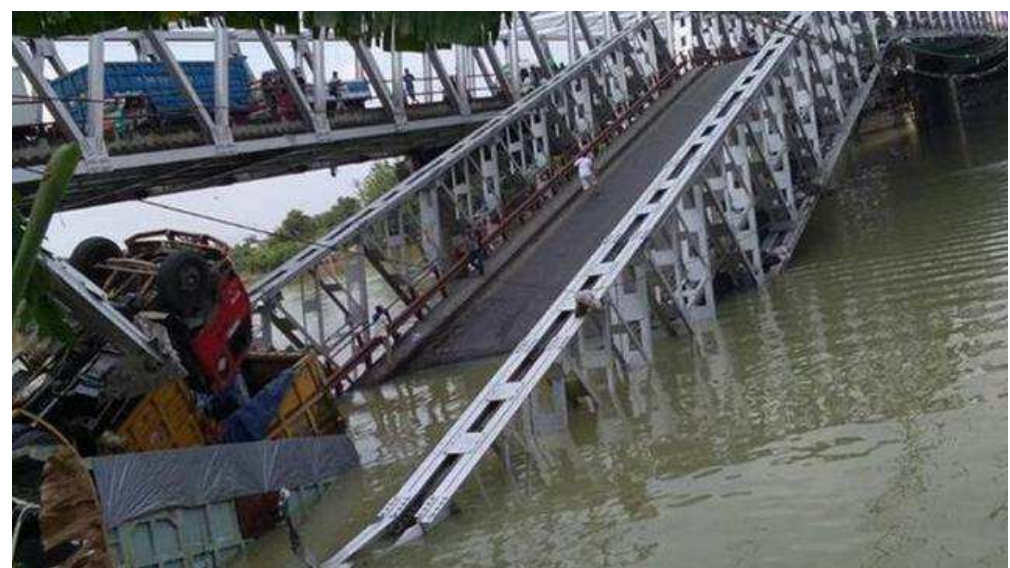

Fig. 2. The Collapse of Cincin Lama Bridge Source: Suara Merdeka Newspaper

Figure 2 shows that road users did not obey the rules regarding the maximum load weight. Moreover, it also showed the lack of supervision which should be carried out by the government.

The government has actually conducted some efforts for surveillance through Implementation Unit of Motorized Vehicle Weighing or known as UPPKB (Unit Pelaksana Penimbangan Kendaraan Bermotor). As regulated in the Minister Regulation No. 134 Year 2015, UPPKB is a subordinate service work unit under BPTD (Balai Pengelola Transportasi Darat-Land Transportation Management Office), Directorate General of Land Transportation, and the Ministry of Transportation which carry out the supervision on freight transportation using electronic weighing equipment.

It is important to conduct supervision on freight transportation burden on the road through UPPKB in order to maintain the condition of road infrastructure. Consequently, it can provide support for good logistics transportation. Road particularly classified as national road which connect provincial capitals and national strategic roads has been the concern to the government.

\subsection{Problems Formulation}

a) How are the Effectiveness and Efficiency of policy weighing motor vehicles on the road?

b) What are Constraints and/or Obstacles in achieving the effectiveness and efficiency of the implementation of policy weighing motor vehicles on the road?

\subsection{Purposes of the Study}

This study aimed to:

a) Analyze the effectiveness and efficiency of the implementation of policy weighing motor vehicles on the road.

b) Analyze the Constraints - Obstacles in achieving the Effectiveness and Efficiency of the implementation of policy weighing motor vehicles on the road. 


\section{Theoretical Concept}

\subsection{Public Policy}

Public policy can be defined as actions, objectives and statements of the government regarding certain problems; the steps which have been or are being taken to be implemented; and the explanations they provide about what has happened or has not happened [3]. Public policy can be simply stated as "what is whatever government decides to do or not to do" [4].

\subsection{Policy Evaluation}

Policy evaluation is one of the stages in policy process, where the stages of the policy process include preparing the agenda, formulating policies, adopting policies, implementing policies and evaluating [5]. Evaluation stage in public policy process is an activity to assess or see the success or failure of a policy/program implementation [6].

Measuring the output level of a policy/program, how big and what is the quality of output of a policy/program

a) Measuring a policy/program impact, at further stage, evaluation is directed to see the positive and negative impacts of a policy/program.

b) Finding out the deviations which might occur by comparing the goals and objectives with the targets achieved.

Thus, it is necessary to determine the indicators as a tool to assess the success of a policy. In addition, there are two indicators used in this study, Effectiveness and Efficiency. These indicators are chosen considering effectiveness can represent output of a policy while policy efficiency represents process of a policy [7].

\subsection{Effectiveness and Efficiency}

Effectiveness may be identified as the ability to clearly choose defined goals or appropriate tools to achieve the stated goals. In other words, an effective manager is able to choose the work to be done or the right way (method) to achieve the goal [8].

Effectiveness level can also be measured by comparing the plans which have been determined with the actual results which have been realized. However, if the effort or results of the work and actions taken are not as what it has been determined that it leads to unachieved goals or the expected goals are not achieved, it is categorized as ineffective.

Effectiveness emphasizes on output whether it is in line with the initial goal, while efficiency focuses on providing an assessment whether the quality of an implementation performance is proportional to the costs incurred [9]. Efficiency in program implementation is not only related to the costs incurred, but also related to the quality of the program, implementation time as well as the resources used. This is due to the fact that many government programs are factually able to be implemented (will produce results). However, in terms of budget time and quality, they are way too far from what has been planned. Thus, a program can be said to be well implemented, if there is the best comparison between the quality of the program with the available cost, time and energy. 


\subsection{Implementation Unit of Motorized Vehicle Weighing}

Weighing Tool or Weighbridge is a set of tools for weighing freight vehicles or trucks which either can be permanently installed or as portable tools which are used to determine the weight of a vehicle and its load used as road supervision or to measure the amount of load on vehicles.

The Functions of the Implementation Unit of Motorized Vehicle Weighing (Pelaksana Penimbangan Kendaraan Bermotor-UPPKB) are:

a) Monitoring function, i.e. to control and/or monitor the tonnage and types of goods load on vehicles in traffic to avoid trucks containing goods which are not permitted by their type or due to its load weight.

b) Enforcing Function, i.e. to maintain and protect road conditions so it is necessary to take action against trucks which violate the road class. For this reason, the government issued regulations on road classes and tonnage on which vehicles could pass.

c) Recording Function, i.e. an administrative function by which each UPPKB is required to record the number of vehicles weighed the size of the load, the number of vehicles which get enforcement action and also writing an official report.

\section{Research Method}

The method used in this study is a qualitative descriptive with Primary Data Sources obtained from observations in the research location, written data and transcripts of interview with informants. In addition, secondary data sources were obtained from photo documentation and supporting data found in the research location. Moreover, the informants in this study were:

a) BPTD (Balai Pengelola Transportasi Darat/Land Transportation Management Office) Region X of Central Java Province and Special Region of Yogyakarta province.

b) The Head Coordinator of UPPKB of Batang regency, Brebes regency and Rembang regency (these three regencies located in Central Java Province).

c) Team Commander (Danru-Komandan Regu) at UPPKB.

d) Drivers of Freight vehicles.

e) Road Users public community.

The research location was at Land Transportation Management Office in three locations in Pantura lane, i.e. UPKB Batang regency, Brebes regency and Rembang regency. The reason for taking this location was because the three-UPPKB units assigning for vehicle motorized weighing have already been active and have important functions in Pantura lane.

\section{Results and Discussion}

\subsection{Effectiveness of the policy of implementing motor vehicles weighing}

Effectiveness emphasizes output whether it is in line with the initial purpose of UPPKB, i.e. to improve road users' safety by maintaining the conditions of road infrastructure. To achieve these objectives, UPPKB has 3 main functions, they are: 


\subsubsection{Monitoring Function}

The tonnage and types of goods loaded on vehicles must be monitored to avoid trucks loading goods which are not permitted based on its type or load weight. The average number of loaded vehicles entering UPPKB to be weighed per month is 26,000-30,000 loaded vehicles. This number is recorded in the data of UPPKB Batang and Rembang. While for Brebes UPPKB, based on observations in the research location, the loaded vehicles passing through the road were mostly disorderly out of the officer's monitoring and they rarely entered UPPKB to be weighed even though almost all of them were heavily loaded. Based on the results of interviews conducted with Brebes UPPKB's Field Officer, Mr. Andi, Brebes UPPKB (UPPKB located in Brebes) has not run optimally because it has only been operating in 2019 and the human resources are officers who will soon be retiring. From the observations at these three UPPKB locations, it could be clearly seen that not all loaded vehicles passing through Pantura lane do weighing at UPPKB. One of the reasons for this was the lack of officers assigned as monitoring officers at the front gate or chasing the violating vehicles.

\subsubsection{Enforcing Function}

To maintain and protect the road condition it is necessary to take enforcement action against trucks which violate the road class. For this reason, the government issued regulations on road class classification and the tonnage on which the vehicle can pass. In reality it was found in research location that enforcement action has been taken by applying ticketing system. At Batang UPPKB, ticket handling with E-ticket application has been carried out since March 27, 2018 until now. The number of UPPKB E-ticketing actions in one month in average reached 2600 vehicles. This e-ticket applies to vehicles with 5-20\% overload of the determined vehicle capacity. The amount of cargo which exceeds the load more than 20 percent from its determined carrying capacity should be enforced strictly. Besides ticket enforcement action, the reduction or transfer the cargo of goods or the excess load should be carried out before the vehicle is allowed to return to the road. In reality, however, this was not done by the three UPPKBs investigated in this study site. Lack of human resources and heavy equipment to reduce the load are the reason given by the implementers in these three UPPKBs.

Here is a transcript excerpt of interview with one of informants, Andi Afianto, an officer at UPPKB Tanjung, Brebes regency.

"All ticketed vehicles and their cargos are allowed to continue their trip; we actually cannot unload the goods because there is no adequate space to put the unloaded goods. Whereas, based on the regulations, the excess must be unloaded or transferred to other vehicles which fit the load".

\subsubsection{Recording Function}

Recording function is an administrative function by which each UPPKB is obligatory required to record the number of vehicles weighed, the size of the load, the number of vehicles which get enforcement action and also writing an official report. This function did run optimally because the recording system has already been assisted by an online operational system which is integrated with the Ministry of Transportation system. Hence, the number of vehicles weighed or enforced can be directly monitored via online network. This system aims to reduce illegal fees which were usually done by the officers. However, 
during observations, not all of these three UPPKBs used this online system. Only Batang UPPKB has used this system optimally.

\subsection{Efficiency of policy Regulation of the Director General of the Ministry of Transportation for Revitalization of Motorized Vehicle Weighing}

The indicators of policy efficiency are described from these three aspects, cost, time and energy.

\subsubsection{Cost}

Based on the observation in this study, the costs spent for the implementation of weighing motor vehicles in three UPPKB locations, Brebes, Batang and Rembang, are quite high. The cost of organizing the weighing implementation includes living costs for officers during their duty shifts or operating costs used for routine operations. This situation is contrary to the revenue received by the officers in UPPKB from the central government. Officers at UPPKB stated that they only received basic salary and there was no special incentive money for transport and food. Ministry of Transpiration has been aware of this problem and has been elaborated in every evaluation of the activities. Nonetheless the realization of this plan is still not certain until this research was carried out. This problem certainly affects the employees' motivation to optimally work in conducting their tasks and functions.

\subsubsection{Time}

To perform the three UPPKB functions maximally, i.e. monitoring, controlling, enforcing and recording for one overloaded vehicle, the researchers during observation calculated the time needed was approximately 10 to 20 minutes, sometimes even more if there was technical constraint. In terms of time, it takes a long time even though the weighing system used is already electronic based and connected to the Ministry of Transportation's online network system.

\subsubsection{Energy}

Based on observation, the researchers found that it needed a high enough energy to handle the implementation of weighing motor vehicles along Pantura lane passing through the traffic in three UPPKBs locations, Brebes, Batang and Rembang. Of which, the number of vehicles to be regulated with the number of personnels mobilized for controlling and enforcing goods transport is not adequate at all and even lacks. Of the three UPPKBs studied, Batang was one of the UPPKBs whose quite high traffic. Moreover, Batang UPPKB had a total 41 personnel with 4 shift groups in a shift working model. One shift consisted of 9-10 people with 8 hours working hours per day. Even with this alternating model, the researchers could identify that there were still many health problems experienced by officers. 
4.3 Constraints in Policy Implementation of Director General Regulation of Land Transportation No. SK.3723/AJ.005/DRJD/2018 on Road Map for Revitalizing the Implementation of Motorized Vehicle Weighing year 2017-2024

\subsubsection{Human Resources}

There were various obstacles in the policy implementation of the Minister of Transportation's Regulation regarding the implementation of weighing motor vehicles in three points of Pantura lane UPPKBs, Brebes, Batang and Rembang. One of the obstacles is human resources (HR) factor. Human resources have a very important role in carrying out the implementation of weighing motorized vehicles. The human resources owned by the three UPPKBs in Pantura lane were still insufficient if compared to the number of vehicles passing through in average daily traffic (LHR-Lalu Lintas Harian Rata-rata/Average daily traffic) or to the number of vehicles which violate the rules. This is as stated by the Ministry of Transportation that there are competency and lack of human resources issues in implementing this policy.

\subsubsection{Lack of Facilities and Infrastructure}

Of the three UPPKBs investigated, one of which, Batang UPPKB, has used Online Information System in weighing and recording processes. Meanwhile, the other two UPPKBs are still not using online system in recording process. Furthermore, in enforcing function, the three UPPKBs did not have heavy equipment which could help the officers reduce the overloading goods. Thus, vehicles with more than $20 \%$ allowed cargo/load only got ticketing and fine action.

\subsubsection{Community Participation}

The obstacles in implementing the policy regulations in monitoring goods transportation which exceeds the loads carried out by UPBKB Brebes, Batang and Rembang surprisingly also came from outside of the organization. The inhibiting factors from outside of the organization were many from vehicle drivers who were lack of awareness in obeying the amount of cargo permitted, as well as obeying the procedures for loading goods transport cargo. Freight drivers rarely or never thought about road safety and even cared about maintaining road infrastructure.

\section{Conclusion}

Based on indicators presented as the results of the research, it can be concluded that all policy implementation of the Director General of Land Transportation Regulation Number SK.3723/AJ.005/DRJD/2018 on Road Map Revitalization of Motorized Vehicle Weighing Year 2017-2024 is conducted in three UPPKBBs, i.e. Brebes, Batang and Rembang. The purposes of this policy are to improve the safety of road users and to maintain the condition of road infrastructure by providing three functions to UPPKBs, i.e. monitoring, enforcing, and recording. When viewed from the implementation process perspective, it has not been maximally carried out due to the lack of facilities used and the personals carrying out the 
regulation were not still based on the regulation which has been set with Standard Operating Procedures (SOP) reference. In addition, the low level of public awareness in road safety has led to the high number of overloaded vehicles in Pantura lane.

\section{References}

[1] W. K. Aji, "Analysis Capacity of Policy Resources for the Implementation of Motor Vehicles Weighing in Central Java," J. Public Policy Manag. Rev., vol. 8, no. 3, pp. 1-18, 2019.

[2] G. H. Brundtland, "Public health challenges in a globalizing world," Eur. J. Public Health, vol. 15, no. 1, pp. 3-5, 2005.

[3] A. Wahab, Analisis Kebijakan. Bumi Aksara, 2012.

[4] J. M. Shafritz, C. Borick, E. W. Russell, and A. C. Hyde, Introducing public administration. Routledge, 2016.

[5] W. N. Dunn, K. Staronova, and S. Pushkarev, "Implementation: The missing link," Implement. Missing Link Public Adm. Reform Cent. East. Eur. Bratislava NISPAcee, pp. 13-25, 2006.

[6] A. G. Subarsono, "Public Policy Analysis: Concepts," Theory Appl. Student Libr. Yogyakarta, 2006.

[7] A. Y. Satria, K. Kismartini, and D. Lituhayu, "Evaluasi Pelaksanaan Kebijakan Bus Rapid Transit Trans Semarang Koridor I Jurusan Mangkang-Penggaron,” J. Public Policy Manag. Rev., vol. 4, no. 4, pp. 160-169, 2015.

[8] T. H. Handoko, "Mengukur kepuasan kerja," Jakarta: Erlangga, 2007.

[9] D. R. Abadi, K. Kismartini, and S. Sundarso, "Evaluasi Program Pemanenan Air Hujan (Rain Water Harvesting) Badan Lingkungan Hidup Kota Semarang," GEMA PUBLICA, vol. 3, no. 1, 2018 